University of Nebraska - Lincoln

DigitalCommons@University of Nebraska - Lincoln

\title{
Influences of Management Regimes on Breeding Bird Densities and Habitat in Mixed-Grass Prairie: An Example from North Dakota
}

\author{
Andrea A. Lueders \\ Colorado State University \\ Patricia L. Kennedy \\ Colorado State University, pat.kennedy@oregonstate.edu \\ Douglas H. Johnson \\ USGS Northern Prairie Wildlife Research Center, Douglas_H_Johnson@usgs.gov
}

Follow this and additional works at: https://digitalcommons.unl.edu/usgsnpwrc

Part of the Other International and Area Studies Commons

Lueders, Andrea A.; Kennedy, Patricia L.; and Johnson, Douglas H., "Influences of Management Regimes on Breeding Bird Densities and Habitat in Mixed-Grass Prairie: An Example from North Dakota" (2006). USGS Northern Prairie Wildlife Research Center. 234.

https://digitalcommons.unl.edu/usgsnpwrc/234

This Article is brought to you for free and open access by the US Geological Survey at DigitalCommons@University of Nebraska - Lincoln. It has been accepted for inclusion in USGS Northern Prairie Wildlife Research Center by an authorized administrator of DigitalCommons@University of Nebraska - Lincoln. 


\title{
Influences of Management Regimes on Breeding Bird Densities and Habitat in Mixed-Grass Prairie: An Example from North Dakota
}

\author{
ANDREA S. LUEDERS, ${ }^{1,2}$ Colorado State University, Graduate Degree Program in Ecology, and Department of Fishery and Wildlife Biology, Fort Collins, \\ CO 80523, USA \\ PATRICIA L. KENNEDY, ${ }^{2}$ Colorado State University, Graduate Degree Program in Ecology, and Department of Fishery and Wildlife Biology, Fort Collins, \\ CO 80523, USA \\ DOUGLAS H. JOHNSON, U.S. Geological Survey, Biological Resources Discipline, Northern Prairie Wildlife Research Center, Department of Fisheries, \\ Wildlife, and Conservation Biology, University of Minnesota, St. Paul, MN 55108, USA
}

(JOURNAL OF WILDLIFE MANAGEMENT 70(2):600-606; 2006)

\section{Key words}

bird populations, bison, breeding birds, cattle, distance sampling, grassland birds, Great Plains, large herbivores, mixed-grass prairie.

It is well known that North American grassland bird populations appear to be declining (Igl and Johnson 1997, Sauer et al. 2004). Most of these birds breed and winter in North America, so declines are likely associated with continental processes (Knopf 1994). Scientists have also observed parallel declines among species that have overlapping breeding ranges but disparate wintering distributions ( $\mathrm{Igl}$ and Johnson 1997). These patterns suggest declines may be linked to problems on the breeding grounds.

Across the Great Plains, the breeding grounds for many of these species, one primary land-use is grazing by domestic cattle. Before European settlement, most of this region was grazed by freeranging herbivores, particularly bison (Hartnett et al. 1997). With settlement, bison were mostly extirpated from the region, and cattle grazing systems were established. This species replacement may have transformed the landscape because bison and cattle grazing regimes differ somewhat (Harnett et al. 1997). Bison and cattle possess slightly different foraging preferences and patterns (Hartnett et al. 1997), and cattle herds are spatially constrained whereas historic bison herds roamed freely (Steuter and Hidinger 1999). Moreover, grassland fire is usually suppressed and rarely prescribed in modern cattle-managed systems, yet during the time of the bison, naturally occurring fires burned at varying frequencies in the Great Plains (Steuter and Hidinger 1999). Today, some land managers are trying to reestablish this ecological condition by reintroducing smaller bison herds to various locations in the region, along with prescribed fire (Hartnett et al. 1997, Griebel et al. 1998). Given this recent trend, it is an opportune time to compare how a widespread, modern land-management regime and a re-created historic regime affect breeding grassland birds.

Only Zimmerman (1997) and Griebel et al. (1998) have compared effects of bison and cattle grazing regimes on birds, in tallgrass prairie and sandhills prairie, respectively. Moreover, only

1 E-mail: andrea.lueders@oregonstate.edu

2 Present address: Eastern Oregon Agricultural Research Center and Department of Fisheries and Wildlife, Oregon State University, Union, OR 97883, USA
Griebel et al. (1998) studied the effects of a bison regime that included fire. Thus, our study is the first to compare effects of these regimes in mixed-grass prairie. Of these 3 studies, ours is also unique because we estimate bird densities using distance sampling. We evaluated bird population densities and their habitats under cattle and bison management regimes in mixedgrass prairie. Our objectives were to 1 ) determine the influence of these different range-management regimes on habitat structure, composition, and heterogeneity; and 2) determine whether bird breeding densities differ between regimes.

\section{Study Area}

We conducted our study in mixed-grass prairie in southwestern North Dakota, USA (Fig. 1). The landscape was characterized by gullied ravines and valleys interspersed with prairie uplands (Hansen et al. 1984). The study area climate was semiarid, with short, warm summers and long, cold winters (Hansen et al. 1984). A mixture of medium-tall bunchgrasses and short grasses dominated the native vegetation in upland areas, including needle-and-thread grass (Hesperostipa comata), western wheatgrass (Pascopyrum smithii), and blue grama (Bouteloua gracilis; Weaver and Albertson 1956). Some shrubs, such as western snowberry (Symphoricarpos occidentalis), and introduced grasses, such as crested wheatgrass (Agropyron cristatum), were also common throughout the area.

Throughout the study area, we established sampling plots in lands subjected to 2 different management regimes. These lands were interspersed throughout Billings, Dunn, McKenzie, and Slope counties in southwestern North Dakota, USA (Fig. 1). Most sampling plots were in cattle-grazed pastures (cattle plots) because cattle gazing was the dominant land used in the study area. The U.S. Forest Service managed these pastures as portions of the Little Missouri National Grassland (LMNG), which encompassed 415,222 ha of land. Based on grazing records from the early 1990s for 12 of these pastures (U.S. Forest Service, Dakota Prairie Grasslands office, Bismark, N. D., USA, unpublished data), stocking rates varied between 0.74 and 1.76 animal unit-months ha ${ }^{-1}$, with an average of 1.13 . Bison had not 
grazed any of these pastures since the late 1800 s, when settlers decimated bison populations in this region. Moreover, prescribed fire had not been a common management tool on the LMNG when we conducted this study, and land managers and ranchers extinguished most wildfires (K. Hansen, U.S. Forest Service, personal communication).

We also established sampling plots in lands grazed by bison (bison plots). The National Park Service managed these lands as Theodore Roosevelt National Park (THRO). The THRO encompassed 2 parcels, which collectively comprised 28,421 ha (North Unit, 9,741 ha; South Unit, 18,680 ha; National Park Service 2001). Throughout each year of our study, 200-250 bison grazed freely throughout the North Unit, and 450-500 bison grazed throughout the South Unit (P. Andersen, National Park Service, personal communication). Bison stocking rates on grazeable acres in each unit were approximately 0.28 and 0.31 animal unit-months $\mathrm{ha}^{-1}$, respectively. Few cattle have grazed THRO since the early 1960s; a small herd $(<20)$ of longhorn cattle grazed the North Unit, but we never observed them on our plots. Unlike the LMNG, the National Park Service sporadically used fire as a management tool in portions of THRO.

\section{Methods}

We located sampling plots nonrandomly to satisfy an objective of our related study (Fontaine et al. 2004). Each sampling plot was a 100-m-radius circular area for bird and habitat sampling. Interplot distances were at least 200-300 m between plot centers, and plots within the same pasture or portion of THRO were arranged along a linear transect. Plots generally did not overlap any fences or include portions of adjacent pastures, although we located some plots adjacent to livestock water developments based on requirements for the Fontaine et al. (2004) study. We collected data at 83 plots in 1999 (64 cattle plots and 19 bison plots) and at 200 plots in 2000 (168 cattle plots and 32 bison plots).

We conducted bird surveys during May to July of 1999 and 2000. In each year, we conducted surveys twice at each sampling plot to account for variation in breeding phenology among species. Sampling period dates were 1-29 June and 23 June-10 July 1999, and 20 May-12 June and 17 June-5 July 2000. Each year, we commenced sampling at plots in the southern portion of the study area and proceeded to higher-latitude plots as each sampling period progressed to sample all plots under similar phenological conditions.

Observers completed each survey between sunrise and 3.5 hours afterwards. We did not conduct surveys in fog or precipitation or when average wind speeds exceeded $3.5 \mathrm{~m} /$ second. Surveys lasted 5 minutes, during which the observer recorded each visually or aurally detected bird, noting its species and sex, if possible. We did not include juvenile birds or "flyovers" (birds that did not seem to have territories in the plot and merely flew over it) in data analyses.

We employed distance sampling methodology (Buckland et al. 1993) during surveys to estimate bird densities. The observer recorded the distance at which each bird was first observed and assigned it to a distance category: 0-25 m, 25-50 m, 50-75 m, or 75-100 m. We selected these categories a priori based on distance sampling recommendations. Before the beginning of sampling each year, observers trained themselves in distance estimation and

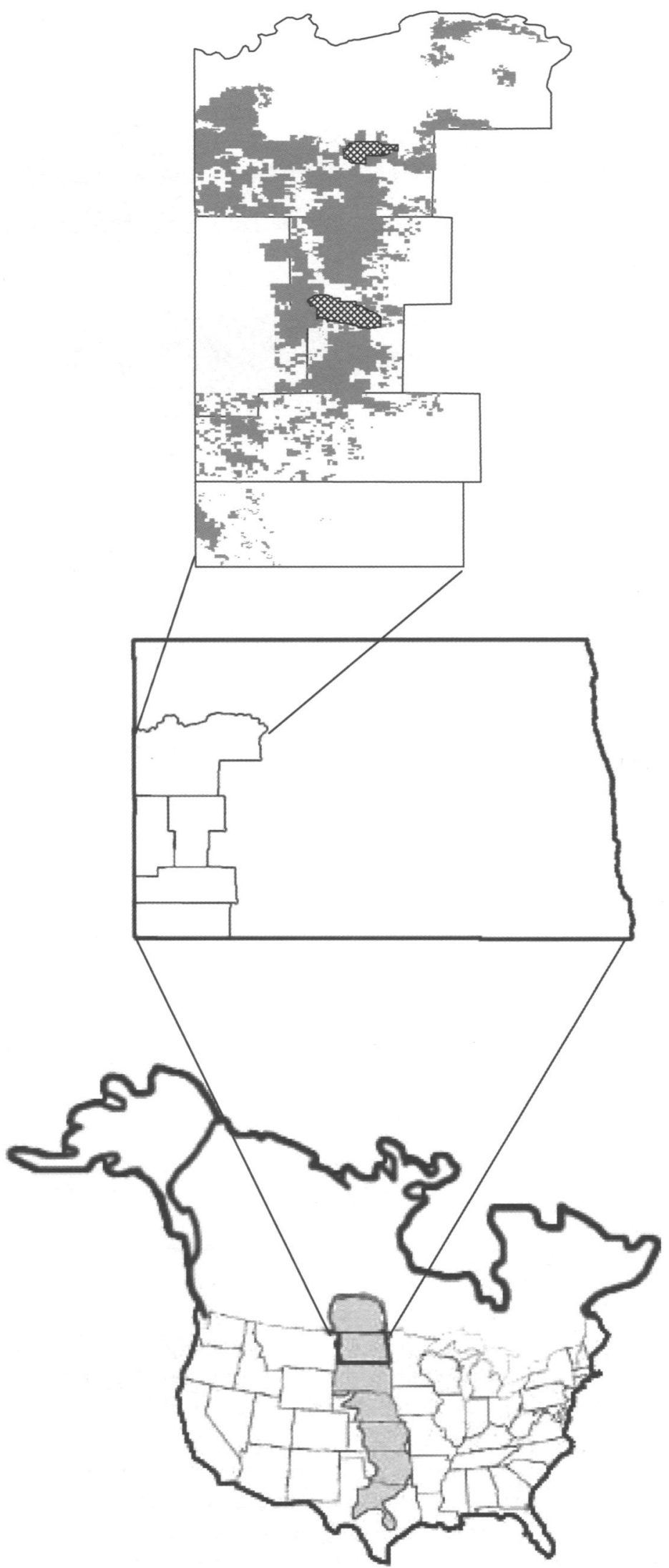

Figure 1. The historical range of mixed-grass prairie in North America (bottom figure), the 4- county area in N. D., USA, that encompasses the study area (middle figure), and the study area itself (top figure) in which bird and habitat sampling plots were located in 1999 and 2000. Sampling plots were located in cattle-grazed pastures not managed with fire (at the Little Missouri National Grassland, depicted in the gray area in the top figure) and in lands managed with bison grazing and fire (Theodore Roosevelt National Park, depicted in the cross-hatched area in the top figure). 
Table 1. Habitat cover type and amount (\%), vegetation height-density (dm), litter depth $(\mathrm{cm})$, and coefficients of variation (CV) of these measures collected at sampling plots under 2 different management regimes in N. D., USA, in 1999 and 2000.

\begin{tabular}{|c|c|c|c|c|c|c|c|c|}
\hline \multirow[b]{3}{*}{ Variable $^{a}$} & \multicolumn{4}{|c|}{ Cattle $^{a}$} & \multicolumn{4}{|c|}{ Bison ${ }^{b}$} \\
\hline & \multicolumn{2}{|c|}{1999} & \multicolumn{2}{|c|}{2000} & \multicolumn{2}{|c|}{1999} & \multicolumn{2}{|c|}{2000} \\
\hline & $\overline{\mathbf{x}}$ & SD & $\bar{x}$ & SD & $\overline{\mathbf{x}}$ & SD & $\overline{\mathbf{x}}$ & SD \\
\hline Bare ground & 27.0 & 13.0 & 22.4 & 12.5 & 8.6 & 8.3 & 10.3 & 5.9 \\
\hline Grass/sedge & 22.9 & 6.7 & 35.3 & 7.0 & 28.7 & 4.5 & 29.2 & 7.2 \\
\hline Forb & 10.3 & 5.0 & 11.7 & 6.2 & 8.9 & 2.5 & 14.7 & 6.1 \\
\hline Litter & 27.2 & 9.0 & 24.6 & 7.8 & 47.5 & 7.1 & 25.9 & 6.4 \\
\hline Cattle/bison dropping & 3.5 & 1.8 & 3.5 & 2.6 & 1.4 & 0.7 & 1.2 & 1.0 \\
\hline Shrub & 0.7 & 1.6 & 0.4 & 1.2 & 2.3 & 3.2 & 18.5 & 14.1 \\
\hline Dead standing forb & 0.3 & 0.7 & 0.1 & 0.9 & 0.9 & 1.6 & 0.3 & 0.6 \\
\hline Cactus & 0.6 & 1.1 & 0.1 & 0.8 & 0.1 & 0.2 & 0.1 & 0.4 \\
\hline Rock & 0.4 & 1.5 & 0.2 & 1.2 & 0.0 & 0.1 & 0.0 & 0.1 \\
\hline Clubmoss & 5.6 & 7.9 & 2.3 & 5.1 & 1.0 & 2.8 & 1.8 & 2.8 \\
\hline Lichen & 2.2 & 3.0 & 0.2 & 0.5 & 0.4 & 0.8 & 0.1 & 0.2 \\
\hline $\begin{array}{l}\text { Height-density } \\
\quad \text { (using Robel pole) }\end{array}$ & 0.9 & 0.6 & 0.7 & 0.3 & 2.1 & 0.9 & 1.5 & 0.5 \\
\hline Litter depth & 1.8 & 1.5 & 1.2 & 0.7 & 4.0 & 1.8 & 2.1 & 0.7 \\
\hline $\mathrm{CV}$ of bare ground ${ }^{\mathrm{C}}$ & 0.4 & 0.3 & 0.4 & 0.2 & 0.6 & 0.3 & 0.6 & 0.3 \\
\hline CV of grass/sedge & 0.2 & 0.1 & 0.2 & 0.2 & 0.2 & 0.1 & 0.3 & 0.1 \\
\hline CV of forb & 0.4 & 0.3 & 0.4 & 0.3 & 0.4 & 0.3 & 0.6 & 0.3 \\
\hline CV of litter & 0.3 & 0.2 & 0.3 & 0.2 & 0.1 & 0.1 & 0.3 & 0.2 \\
\hline $\mathrm{CV}$ of cattle/bison dropping & 0.4 & 0.3 & 0.6 & 0.3 & 0.8 & 0.6 & 1.0 & 0.5 \\
\hline $\mathrm{CV}$ of shrub & 1.3 & 0.3 & 1.3 & 0.2 & 1.4 & 0.3 & 0.9 & 0.5 \\
\hline CV of dead standing forb & 1.4 & 0.3 & 1.4 & 0.1 & 1.4 & 0.4 & 1.5 & 0.2 \\
\hline CV of cactus & 1.5 & 0.3 & 1.5 & 0.1 & 1.5 & 0.2 & 1.5 & 0.1 \\
\hline CV of rock & 1.3 & 0.3 & 1.4 & 0.2 & 1.4 & 0.2 & 1.5 & 0.2 \\
\hline CV of clubmoss & 1.0 & 0.5 & 1.2 & 0.3 & 1.3 & 0.2 & 1.3 & 0.2 \\
\hline CV of lichen & 1.0 & 0.5 & 1.1 & 0.3 & 1.3 & 0.3 & 1.3 & 0.3 \\
\hline CV of height-density & 0.4 & 0.2 & 0.4 & 0.2 & 0.3 & 0.2 & 0.5 & 0.2 \\
\hline
\end{tabular}

${ }^{a}$ Plots located in cattle-grazed pastures not managed with fire.

${ }^{b}$ Plots located in lands managed with bison grazing and fire.

c Standard deviations of $\mathrm{CV}$ values were calculated by the following method: 1) calculating the mean, standard deviation, and CV among all subplot values for a habitat variable at a given plot; and 2) calculating an average and standard deviation of all CV values for that habitat variable for a given management regime/year combination. This second step yields the "CV" and "SD" values presented here. We measured litter depth at only 1 subplot in the 1999 habitat surveys, so we could not calculate subplot standard deviations and $\mathrm{CV}$ values for that variable.

bird identification to standardize data collection. Two observers collected data each year.

During both years, we conducted a habitat survey at each plot. We conducted surveys once during 5-29 June 1999, and twice during 17 May-4 July 2000. Each habitat survey consisted of 3 to 5 subplots within each plot. Our habitat sampling design was based on protocols established by the Breeding Biology Research and Monitoring Database (BBIRD; Martin et al. 1997) but modified to fit our study design. Most subplots were 5-m-radius circles; we located 1 subplot at the plot center and 4 subplots $50 \mathrm{~m}$ from the center in the 4 cardinal directions. Plots adjacent to livestock water developments were semicircles. At these plots, we established 1 semicircular subplot at the center and 2 circular subplots $50 \mathrm{~m}$ from the center at $45^{\circ}$ and $315^{\circ}$ from the compass bearing of the transect.

At each subplot, we measured variables that characterized habitat structure, canopy cover composition, and heterogeneity in these measures (Table 1). We measured height-density of vegetation (Robel et al. 1970) and litter depth in each cardinal direction from the subplot center and visually estimated cover percentages of several cover types.

We calculated bird densities using analysis techniques (Buckland et al. 1993) and software (DISTANCE 3.5; Thomas et al. 1998) that are appropriate for distance sampling data. We estimated densities for the most common species: Baird's sparrows (Ammodramus bairdii), chestnut-collared longspurs (Calcarius ornatus), grasshopper sparrows (Ammodramus savannarum), and western meadowlark (Sturnella neglecta) in both years, and additionally, for horned lark (Eremophila alpestris), lark bunting (Calamospiza melanocorys), Sprague's pipit (Anthus spragueii), bobolink (Dolichonyx oryzivorus), and Savannah sparrow (Passerculus sandwichensis) in 2000, when we collected more data. We observed several additional species but could not estimate their densities because of the limited number of detections. Buckland et al. (1993) recommend at least 40-60 detections per species for reliable estimation of detection probabilities, and subsequently, densities. For each species, we used observations of both males and females to generate overall densities and $95 \%$ confidence intervals by management regime and year. We compared each species' densities between regimes by examining the degree of confidence interval overlap. We did not analyze density differences using tests of statistical significance because confidence intervals can be more informative than such tests (Johnson 1999).

For each year, we summarized habitat data by calculating means and standard deviations of each habitat variable by management regime. First, we calculated means and standard deviations for each plot, based on subplot values and weighted by subplot sizes. We then generated grand means for both regimes by averaging values across plots and, in 2000, across sampling periods (PROC MEANS; SAS Institute 1990). We generated coefficients of variation for each variable by year. We used coefficients of variation instead of standard deviation as a final measure of relative within-plot heterogeneity because the latter measure tends to correlate with its associated mean (Sokal and Rohlf 1981). Moreover, we conducted a principal components analysis (PCA) of habitat variables to summarize yearly patterns in habitat structure and composition by regime (PROC PRINCOMP; SAS 1990). The PCA graphs are useful tools for examining patterns in complex data sets and overcoming the potential problem of correlated variables (Montgomery and Peck 1992).

\section{Results}

Qualitative contrasts between suites of species found under the 2 regimes were apparent (Table 2). We observed 30 and 20 species at cattle and bison plots, respectively. We detected 4 species of the most common at cattle plots but not at bison plots (horned larks, Sprague's pipits, chestnut-collared longspurs, and lark buntings), and we detected 1 species (the bobolink) on bison plots and not on cattle plots during 1 year. These differences were likely partially affected by sampling effort differences between management regimes (which was a function of the acreage of each regime in the study area). Nevertheless, cattle plots clearly were used by a wider diversity of grassland birds than were bison plots.

Of those species found in both regimes, we observed differences in bird densities (Table 3). Two of the most common species, 
Table 2. Percentage of sampling plots at which each bird species was observed during grassland surveys in N. D., USA, in 1999 and 2000.

\begin{tabular}{lrr}
\hline Species & \multicolumn{2}{c}{ Cattle } \\
& Bison \\
\hline Killdeer (Charadrius vociferus) & 0.86 & 0.00 \\
Marbled godwit (Limosa fedoa) & 1.72 & 0.00 \\
Willet (Catoptrophorus semipalmatus) & 0.43 & 0.00 \\
Upland sandpiper (Bartramia longicauda) & 3.02 & 0.00 \\
Northern harrier (Circus cyaneus) & 0.43 & 2.00 \\
Swainson's hawk (Buteo swainsoni) & 0.43 & 0.00 \\
Sharp-tailed grouse (Tympanuchus phasianellus) & 1.72 & 4.00 \\
Mourning dove (Zenaida macroura) & 6.03 & 6.00 \\
Eastem kingbird (Tyrannus tyrannus) & 3.02 & 0.00 \\
Westem kingbird (Tyrannus verticalis) & 1.72 & 2.00 \\
Northern rough-winged swallow & & \\
(Stelgidopteryx serripennis) & 0.86 & 0.00 \\
Cliff swallow (Hirundo pyrrhonota) & 2.16 & 0.00 \\
Barn swallow (Hirundo rustica) & 5.17 & 4.00 \\
American crow (Corvus brachyrhynchos) & 0.43 & 6.00 \\
Horned lark (Eremophila alpestris) & 19.40 & 0.00 \\
Sprague's pipit (Anthus spragueii) & 6.47 & 0.00 \\
Common yellowthroat (Geothlypis trichas) & 0.43 & 20.00 \\
Spotted towhee (Pipilo maculatus) & 0.00 & 4.00 \\
Grasshopper sparrow (Ammodramus savannarum) & 92.24 & 90.00 \\
Baird's sparrow (Ammodramus bairdii) & 59.05 & 8.00 \\
Vesper sparrow (Pooecetes gramineus) & 2.59 & 6.00 \\
Savannah sparrow (Passerculus sandwichensis) & 15.95 & 8.00 \\
Clay-colored sparrow (Spizella pallida) & 0.00 & 6.00 \\
Chestnut-collared longspur (Calcarius ornatus) & 60.78 & 0.00 \\
Lark bunting (Calamospiza melancorys) & 23.71 & 0.00 \\
Bobolink (Dolichonyx oryzivorus) & 6.03 & 38.00 \\
Western meadowlark (Sturnella neglecta) & 75.86 & 42.00 \\
Yellow-headed blackbird (Xanthocephalus xanthocephalus) & 0.00 & 2.00 \\
Red-winged blackbird (Agelaius phoeniceus) & 5.17 & 8.00 \\
Brown-headed cowbird (Molothrus ater) & 6.47 & 2.00 \\
Common grackle (Quiscalus quiscula) & 4.31 & 6.00 \\
American goldfinch (Carduelis tristis) & 0.43 & 2.00 \\
\hline & & \\
\hline
\end{tabular}

${ }^{a}$ Cattle = plots located in cattle-grazed pastures that were not managed with fire. Data were pooled over 1999 and 2000; they were collected at 64 and 168 plots, respectively, for a total of 232 plots.

${ }^{\mathrm{b}}$ Bison = plots located in lands managed with bison grazing and fire. Data were pooled over 1999 and 2000; they were collected at 18 and 32 plots, respectively, for a total of 50 plots.

grasshopper sparrow and western meadowlark, were at similar densities in the 2 regimes both years. However, Baird's and Savannah sparrow densities were higher in cattle plots during the same period. A less common species, bobolink, was at a higher density at bison plots than at cattle plots in 2000 (the pattern for 1999 is unknown because of insufficient detections).

Each year, detection probabilities did not differ between regimes (Table 3). In 1999, detection probabilities for chestnut-collared longspur and grasshopper sparrow were $<1.0$, indicating we were not detecting all individuals during our surveys. In 2000, the detection probability of these 2 species equaled 1.0 , but detectability of Savannah sparrows was $<1.0$. In all cases, when detection probabilities were $<1.0$, we corrected for this undercounting using distance sampling methods (Buckland et al. 1993).

Detection functions for most species suggested possible responsive movement, indicating birds may have moved away from the plot centers in response to our presence. This may bias density estimates low (Buckland et al. 1993). Lueders (2002) conducted computer simulations of this behavior to estimate the magnitude of bias for some of these species. Based on the simulations, grasshopper sparrow densities in 1999 may have been
Table 3. Density estimates (birds/100 ha), confidence intervals $(95 \%)$, and detection probabilities for the 9 most common bird species observed under 2 management regimes in N. D., USA, in 1999 and 2000.

\begin{tabular}{|c|c|c|c|c|c|}
\hline Species & Year & $\begin{array}{l}\text { Management } \\
\text { regime }^{a}\end{array}$ & Density & $\begin{array}{c}95 \% \\
\mathrm{Cl}\end{array}$ & $\begin{array}{l}\text { Detection } \\
\text { probability }\end{array}$ \\
\hline \multirow{4}{*}{$\begin{array}{l}\text { Chestnut-collared } \\
\text { longspur }\end{array}$} & 1999 & Cattle & 28.2 & $18.6-37.8$ & 0.97 \\
\hline & & Bison & 0.0 & & 0.97 \\
\hline & 2000 & Cattle & 40.3 & $33.9-46.7$ & 1.00 \\
\hline & & Bison & 0.0 & & 1.00 \\
\hline \multirow[t]{2}{*}{ Horned lark ${ }^{\mathrm{b}}$} & 2000 & Cattle & 11.1 & $7.0-15.2$ & 1.00 \\
\hline & & Bison & 0.0 & & 1.00 \\
\hline \multirow[t]{2}{*}{ Lark bunting $^{b}$} & 2000 & Cattle & 17.9 & $9.7-26.1$ & 1.00 \\
\hline & & Bison & 0.0 & & 1.00 \\
\hline \multirow[t]{4}{*}{ Grasshopper sparrow } & 1999 & Cattle & 69.1 & $61.5-76.7$ & 0.76 \\
\hline & & Bison & 46.1 & $26.7-65.5$ & 0.76 \\
\hline & 2000 & Cattle & 61.5 & $55.5-67.4$ & 1.00 \\
\hline & & Bison & 69.6 & $61.0-78.2$ & 1.00 \\
\hline \multirow[t]{2}{*}{ Sprague's pipit ${ }^{b}$} & 2000 & Cattle & 2.2 & $0.9-3.6$ & 1.00 \\
\hline & & Bison & 0.0 & & 1.00 \\
\hline \multirow[t]{4}{*}{ Western meadowlark } & 1999 & Cattle & 25.3 & $18.7-31.8$ & 1.00 \\
\hline & & Bison & 11.7 & $1.9-21.5$ & 1.00 \\
\hline & 2000 & Cattle & 31.8 & $24.3-39.3$ & 1.00 \\
\hline & & Bison & 21.9 & $11.6-32.2$ & 1.00 \\
\hline \multirow[t]{4}{*}{ Baird's sparrow } & 1999 & Cattle & 15.9 & $11.3-20.5$ & 1.00 \\
\hline & & Bison & 1.7 & $-1.6-5.0$ & 1.00 \\
\hline & 2000 & Cattle & 28.3 & $24.4-32.2$ & 1.00 \\
\hline & & Bison & 6.0 & $0.8-11.1$ & 1.00 \\
\hline \multirow[t]{2}{*}{ Bobolink $^{b}$} & 2000 & Cattle & 1.5 & $-0.3-3.3$ & 1.00 \\
\hline & & Bison & 20.0 & $9.5-30.4$ & 1.00 \\
\hline \multirow[t]{2}{*}{ Savannah sparrow ${ }^{b}$} & 2000 & Cattle & 5.9 & $3.5-8.2$ & 0.86 \\
\hline & & Bison & 1.2 & $-1.1-3.4$ & 0.86 \\
\hline
\end{tabular}

a Plots were located in either cattle-grazed pastures managed without fire or lands managed with bison grazing and fire. Sample size $(n)$ of plots were cattle $=64$ and bison $=18$ in 1999; cattle $=168$ and bison $=32$ in 2000 .

${ }^{b}$ Densities were not estimated for this species in 1999 because of insufficient detections.

biased $-7 \%$, chestnut-collared longspur and grasshopper sparrow densities in 2000 may have been biased $-36 \%$, and Savannah sparrow densities in 2000 may have been biased $-29 \%$. The effect of these biases on our analyses is unclear, but we have no reason to expect that management regime influenced the probability of responsive movement because detection probabilities did not differ between regimes.

Means and standard deviations of habitat variables differed somewhat between regimes, although standard deviations were often large (Table 1). Percentage of bare ground was generally higher at cattle plots than at bison plots. Percentage of shrub cover was notably higher at bison plots in 2000 .

The PCA provided a more apparent distinction in habitat features between regimes. The PCA produced 9 principal components with eigenvalues $>1$, and these components collectively accounted for $70 \%$ of the variation in the 25 habitat variables. The first (Prin 1) and second (Prin 2) components accounted for $16 \%$ and $11 \%$ of the total variation, respectively. Prin 1 characterized a gradient in habitat structure from a dense, tall, grass- and litter-dominated habitat type to a type with high amounts of bare ground, cattle/bison droppings, and high patchiness in grass cover. Prin 2 generally represented habitat heterogeneity, depicting a gradient from high variability in shrub cover to high shrub cover and high variability in other cover measures. 
For each year, we graphed the first 2 principal component values for each plot to depict the position of the 2 regimes in principal component space (Fig. 2). In 1999, cattle plots had shorter, sparser vegetation than bison plots, and bison plots had higher shrub cover and higher variability in several cover measures than cattle plots (Fig. 2a). We observed annual variability in these patterns. In 2000 , cattle and bison plots were similar in their relationship to Prin 1, although some cattle plots lay closer to the positive end, indicating sparser habitat structure (Fig. 2b).

\section{Discussion}

As predicted, we observed substantially different patterns of habitat structure between regimes. At many of the bison plots, much of the higher habitat structure and shrub cover was due to more western snowberry cover than in the cattle plots. Both bison and cattle will eat young western snowberry shoots (K. Hansen, U.S. Forest Service, personal communication; J. Norland, North Dakota State University, personal communication); hence the higher prevalence of this shrub at bison plots may be a result of high shoot-establishment rates as a function of lower grazing intensity. Furthermore, fire is known to increase western snowberry cover (Anderson and Bailey 1979) if it is not burned on a frequent (annual) basis (Bork et al. 1997). As previously mentioned, THRO staff burned each portion of the park infrequently.

We also observed differences in habitat heterogeneity between regimes (Fig. 2b). Bison plots had substantially higher heterogeneity in overall cover than cattle plots did. This difference may have been due to lower levels and greater heterogeneity of stocking rates at these plots. This pattern supports Fuhlendorf and Engle's (2001) contention that traditional rangeland management practices reduce landscape heterogeneity of rangelands by promoting uniform distribution of livestock grazing across landscapes.

What is interesting about our results is that neither species richness nor bird densities were higher in the structurally more diverse habitat. We did not observe 4 species (chestnut-collared longspur, horned lark, lark bunting, and Sprague's pipit) in bison plots, where habitat structure and heterogeneity was higher than in the cattle plots. We did encounter these 4 species in the cattle plots, however. In our study, more birds chose the cattle-grazed habitat over the bison-grazed habitat for breeding season use. This difference was probably at least partly due to different habitat preferences among these species; 3 species that we did not observe in the bison plots (chestnut-collared longspur, horned lark, and lark bunting) generally prefer low vegetation structure during the breeding season (Kantrud 1981), such as that found in the cattle plots. Moreover, 2 other species that occurred at higher densities in the cattle plots (Baird's and Savannah sparrows) may avoid shrubby areas (Renken 1983) and were indeed less common in the bison plots. These species also generally prefer higher vegetation cover (Davis and Duncan 1999), so their density patterns between regimes was a bit surprising. Without data on vital rates, food resources, and predation risk it was difficult to determine whether these cattle areas provided the necessary requirements for these species or were serving as ecological sinks (Vickery et al. 1992, Burke and Nol 1998).

We measured plot habitat characteristics but did not evaluate the

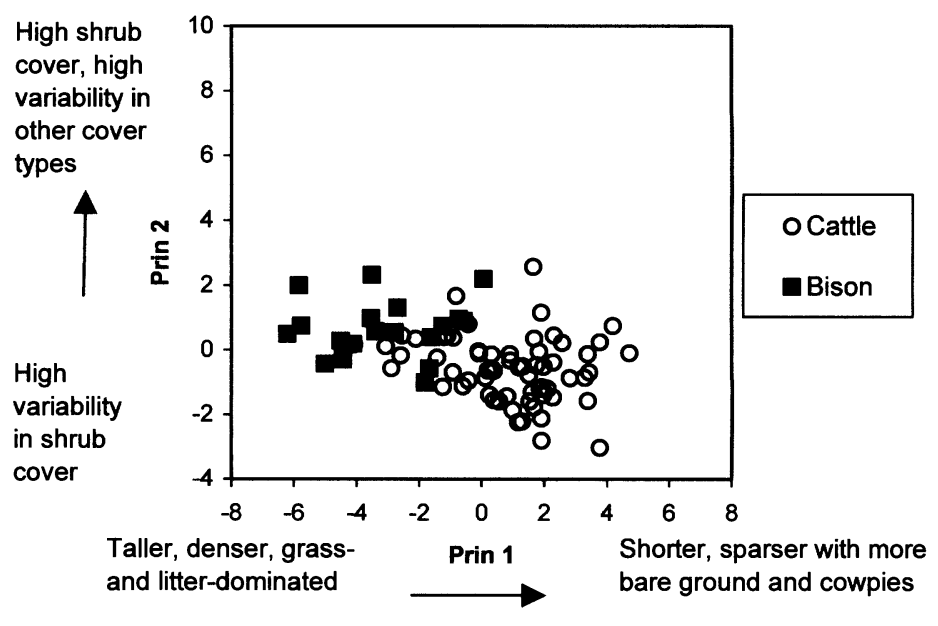

b

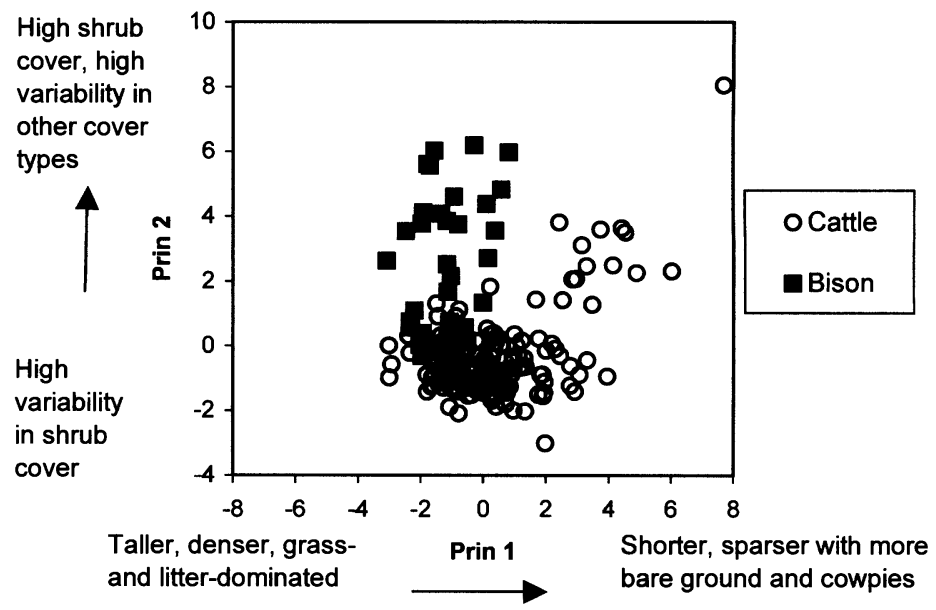

Figure 2. A graph of the sampling plots in relation to the first 2 principal components (Prin 1 and Prin 2) resulting from an analysis of all habitat variables collected at cattle-grazed (cattle) plots not managed with fire, and plots managed with bison grazing and fire (bison) plots in N. D., USA, in (a) 1999, and in (b) 2000.

characteristics of the landscapes in which these plots were embedded. Davis (2004) found that landscape characteristics and vegetation structure were important predictors of breeding bird abundance and occurrence in Saskatchewan mixed-grass prairie. Although Davis' data are difficult to interpret because his abundance data were not adjusted for detection probabilities, his results do suggest that landscape characteristics might be influencing the patterns we observed.

Zimmerman (1997) did not address differences in speciesspecific bird abundances between cattle and bison regimes, but he did address total bird avian abundance. After introducing bison to ungrazed pastures, he observed decreases in total avian abundance, although these decreases were not statistically significant. 
However, these values were not adjusted for detection probability, and his observed plant and avian community composition differed greatly from ours given his tallgrass prairie study area. In sandhills prairie pastures that were managed with either cattle or bison with fire, Griebel et al. (1998) found few differences in bird densities and no differences in vegetation density or height. Grasshopper sparrow densities were similar between regimes, as in our study, but they observed higher western meadowlark densities in cattle-grazed pastures, whereas we observed no differences. Their results may be partially due to the similar stocking intensities in the 2 regimes; in our study, stocking rates varied between regimes, which limits our ability to separate the effects of stocking rate from species of large herbivore. We sampled birds in a local refuge that was not grazed by either species but it was too small to sample effectively and other ungrazed areas did not exist in the study area (see Lueders 2002 for details). We also cannot separate the effects of fire from grazing because there were no areas in this study area that grazed cattle and used prescribed fire or grazed bison without fire.

\section{Management Implications}

Our results provide some evidence that in this region, bird use can be higher under moderate cattle-stocking rates without fire than under a regime of low bison-stocking rates combined with fire. Our ability to draw an inference is somewhat limited, however, by nonrandom site selection, sampling effort differences between management regimes, and the confounding effect of fire and grazing management. Therefore, researchers hoping to thoroughly

\section{Literature Cited}

Anderson, H. G., and A. W. Bailey. 1979. Effects of annual burning on grassland in the aspen parkland of east-central Alberta. Canadian Journal of Botany 58:985-996.

Bork, E. W., R. J. Hudson, and A. W. Bailey. 1997. Populus forest characterization in Elk Island National Park relative to herbivory, prescribed fire, and topography. Canadian Journal of Botany 75:1518-1526.

Buckland, S. T., D. R. Anderson, K. P. Burnham, and J. L. Laake. 1993. Distance sampling: estimating abundance of biological populations. Chapman \& Hall, London, England.

Burke, D. M., and E. Nol. 1998. Influence of food abundance, nest-site habitat, and forest fragmentation on breeding ovenbirds. Auk 115:96-104.

Davis, S. 2004. Area sensitivity in grassland passerines: effects of patch size, patch shape, and vegetation structure on bird abundance and occurrence in southern Saskatchewan. Auk 121:1130-1145.

Davis, S. K., and D. C. Duncan. 1999. Grassland songbird occurrence in native and crested wheatgrass pastures of southern Saskatchewan. Studies in Avian Biology 19:211-218.

Fontaine, A. L., P. L. Kennedy, and D. H. Johnson. 2004. Effects of distance from cattle water developments on grassland birds. Journal of Range Management 57:238-242.

Fuhlendorf, S. D., and D. M. Engle. 2001. Restoring heterogeneity on rangelands: ecosystem management based on evolutionary grazing patterns. Bioscience 51:625-632.

Griebel, R. L., S. L. Winter, and A. A. Steuter. 1998. Grassland birds and habitat structure in sandhills prairie managed using cattle or bison plus fire. Great Plains Research 8:255-268.

Hansen, P. L., G. R. Hoffman, and A. J. Bjugstad. 1984. The vegetation of Theodore Roosevelt National Park, North Dakota: a habitat type classification. U.S. Forest Service General Technical Report RM-113, Fort Collins, Colorado, USA.

Hartnett, D. C., A. A. Steuter, and K. R. Hickman. 1997. Comparative ecology of native and introduced ungulates. Pages 72-101 in F. L. Knopf, and F. B. Samson, editors. Ecological studies, volume 125: ecology and conservation of Great Plains vertebrates. Springer, New York, New York, USA. understand the impacts of different management regimes on grassland bird populations should strive to avoid these sampling problems and, moreover, strive to test regime effects using rigorous experimentation before and after implementation. Furthermore, because higher bird use does not necessarily indicate higher reproductive success or survival (Vickery et al. 1992), researchers should compare avian vital rates across management regimes and examine the factors regulating these vital rates (e.g., predation and food availability) to more thoroughly understand the impacts on these populations.

\section{Acknowledgments}

Financial support for our research was provided by Northern Prairie Wildlife Research Center, the U.S. Forest Service Region 1 office, Colorado State University's College of Natural Resources, the Colorado Division of Wildlife Diversity Scholarship Program, and the J. E. Weaver Small Grants Program of The Nature Conservancy's Nebraska Chapter. We thank the U.S. Forest Service and the National Park Service for allowing us to conduct research on their lands, and the Colorado Cooperative Fish and Wildlife Research Unit and Northern Prairie Wildlife Research Center for providing logistical support. M. F. Dinkins and K. D. Ruffert provided invaluable field assistance, and J. B. Fontaine assisted with data management. D. R. Anderson, K. P. Burnham, A. R. Ellingson, and P. M. Lukacs provided statistical assistance. N. T. Hobbs and J. K. Detling provided helpful advice throughout this project.

Igl, L. D., and D. H. Johnson. 1997. Changes in breeding bird populations in North Dakota: 1967 to 1992-1993. Auk 114:74-92.

Johnson, D. H. 1999. The insignificance of statistical significance testing. Journal of Wildlife Management 63:763-772.

Kantrud, H. A. 1981. Grazing intensity effects on breeding avifauna of North Dakota native grasslands. Canadian Field-Naturalist 95:404-417.

Knopf, F. L. 1994. Avian assemblages on altered grasslands. Studies in Avian Biology 15:247-257.

Lueders, A. S. 2002. Influences of vegetative structure on avian populations under grazing regimes in North Dakota mixed-grass prairie. Thesis, Colorado State University, Fort Collins, USA.

Martin, T. E., C. R. Paine, C. J. Conway, W. M. Hochachka, P. Allen, and W. Jenkins. 1997. BBIRD field protocol. Montana Cooperative Wildlife Research Unit, University of Montana, Missoula, USA. <http://pica.wru.umt.edu/ BBIRD/protocol/veg.htm>. Accessed 2004 Apr 7.

Montgomery, D. C., and E. A. Peck. 1992. Introduction to linear regression analysis. John Wiley \& Sons, New York, New York, USA.

National Park Service. 2001. Acreage by unit. Theodore Roosevelt National Park, U.S. Department of the Interior. <http://www.nps.gov/thro/tr_acres. htm>. Accessed: 2001 Jun 20.

Renken, R. B. 1983. Breeding bird communities and bird-habitat associations on North Dakota Waterfowl Production Areas of three habitat types. Thesis, lowa State University, Ames, USA.

Robel, R. J., J. N. Briggs, A. D. Dayton, and L. C. Hulbert. 1970. Relationships between visual obstruction measurements and weight of grassland vegetation. Journal of Range Management 23:295-297.

SAS Institute. 1990. SAS/STAT user's guide, version 6. Fourth edition. SAS Institute, Cary, North Carolina, USA.

Sauer, J. R, J. E. Hines, and J. Fallon. 2004. The North American Breeding Bird Survey, results and analysis 1966-2000. Version 2004.1. U.S. Geological Survey, Patuxent Wildlife Research Center, Laurel, Maryland, USA. <http://www.mbr-pwrc.usgs.gov/bbs/bbs.html>. Accessed: 2001 Oct 26. 
Sokal, R. R., and F. J. Rohlf. 1981. Biometry. W. H. Freeman, New York, New York, USA.

Steuter, A. A., and L. Hidinger. 1999. Comparative ecology of bison and cattle on mixed-grass prairie. Great Plains Research 9:329-342.

Thomas, L., J. L. Laake, J. F. Detty, S. T. Buckland, D. L. Borchers, D. R. Anderson, K. P. Burnham, S. Strindberg, S. L. Hedley, M. L. Burt, F Marques, J. H. Pollard, and R. M. Fewster. 1998. DISTANCE 3.5. Release 6. Research Unit for Wildlife Population Assessment, St. Andrews, Scotland.

Vickery, P. D., M. L. Hunter, Jr., and J. V. Wells. 1992. Is density an indicator of breeding success? Auk 109:706-710.
Weaver, J. E., and F. W. Albertson. 1956. Grasslands of the Great Plains. Johnsen, Bock, and Webb, Lincoln, Nebraska, USA.

Zimmerman, J. L. 1997. Avian community responses to fire, grazing, and drought in the tallgrass prairie. Pages 167-180 in F. L. Knopf, and F. B. Samson, editors. Ecological studies, volume 125: ecology and conservation of Great Plains vertebrates. Springer, New York, New York, USA.

Associate Editor: Kendall. 